\title{
Rural Revitalization: How to Develop Rural Tourism
}

\author{
Zeng Sishi ${ }^{*}$, Liu Wangminna ${ }^{2}$, He Jiaqi $^{3}$ \\ ${ }^{1}$ Department of Public Administration, Nanfang College of Sun Yat-sen University, Guangzhou, Guangdong, 510000, \\ China \\ ${ }^{2}$ Zhujiang College of South China Agricultural University, Guangzhou, Guangdong, 510000, China \\ ${ }^{3}$ Department of Public Administration, Nan fang College of Sun Yat-sen University, Guangzhou, Guangdong, 510000, \\ China \\ "Corresponding author. Email:251135392@qq.com
}

\begin{abstract}
In 2016, the No. 1 central document put forward the directive of "perfecting rural financial services", "guiding Internet finance, and developing standardized rural finance in rural areas", giving full attention to the modern rural financial system. Rural tourism investment has grown rapidly. In 2017, the actual investment of rural tourism in China reached 550 billion yuan, with more than 2.5 billion person times received annually. However, rural tourism investment must pay attention to the field and mode of rural tourism investment. We should change the investment content from single product construction to characteristic rural B \& B, resort hotel, historical and cultural village, leisure farm and so on to broaden the field of rural tourism investment; we should strengthen financial support, guide financial capital investment, increase credit support, implement preferential tax policies, expand tourism financing channels, and diversify and innovate rural tourism investment mode.
\end{abstract}

Keywords : Rural Revitalization; rural tourism; beautiful China; well-off society

\section{PREFACE}

Lucid waters and Lush mountains are invaluable assets ", in August 2005, general secretary Xi Jinping in Anji, Huzhou, clarified the importance of rural tourism in China. The report of the 19th National Congress of the Communist Party of China put forward the strategy of rural revitalization, "accelerate the reform of ecological civilization system, and build a beautiful China". Beautiful countryside is an important part of the construction of beautiful China, and also an important content of building a moderately prosperous society in rural areas. On the one hand, it shows that the "three rural" issues occupy an important position in the work of the Party Central Committee; on the other hand, it also points out the direction for the realization of agricultural and rural modernization. In today's China, hundreds of millions of people head high to realize the "two 100 years" goal and build a well-off society in an all-round way. "well -off or not, the key to see the fellow villagers". Naturally, the rural tourism has become the main battlefield of the "two centenary" well-off society. With the extension of the tourism market, China's rural tourism urgently meets the development needs of the new era and uses new technologies Concept, to achieve a breakthrough in the industry. Rural Transformation and adaptive evolutionary path is an important research content in the field of rural sustainable development, which has important theoretical and practical significance for the implementation of rural revitalization strategy and the realization of its multiple objectives.[1] How to do a good job in rural tourism in the new period, combined with the requirements of the times, further promote innovation, promote breakthrough, promote development, promote protection, promote beauty, and create distinctive, beautiful and nostalgic rural tourism with Chinese characteristics has become an important proposition of tourism supply side reform and the current era background. How to achieve the all-round development of "agriculture, rural areas and farmers", realize the "agricultural industrialization", "farmers in the land", "rural scenic spots", comprehensive linkage and rural related production, life and ecological development, so as to upgrade China's rural tourism from the traditional development to the living destination of rural tourism.

\section{THE DEVELOPMENT PROSPECT OF RURAL TOURISM}

Rural tourism has distinct characteristics and diverse functions. Therefore, it can be predicted that rural tourism has a bright development prospect. The main basis is as follows:

\subsection{The change of consumption concept}

With the advent of the 21st century, great changes have taken place in people's original values and consumption views. People begin to realize that tourism is a new way to improve the spiritual level and optimize the quality of life. It is a pursuit of spirit and life quality, but not simply a 
rest and adjustment after work. At the same time, people's concept of tourism has changed greatly. With the enrichment of tourism experience, more and more tourists are no longer satisfied with the tired way of "on-the-spot" travel, and the demand of tourism begins to shift from "surface Tour" to "experience tour". In this context, rural tourism, as a healthy, avant-garde and personalized consumption mode, begins to occupy a more and more important position in people's life.

\subsection{The increase of life pressure}

In modern society, people's economic income is generally increased, but the quality of life is also significantly reduced because of the increasing work pressure. With the rapid development of national industrialization and urbanization, people's life pace is faster and faster, and the competition environment is more and more intense. Therefore, people are more and more eager to get rid of the city life and enter the countryside to relieve the pressure and loosen body and mind. At the same time, due to the acceleration of industrialization, many modern metropolises have formed obvious heat island effect and reinforced concrete phenomenon, which has brought huge life pressure to urban residents, and then produced modern urban civilization diseases such as high-rise building disease, depression and sub-health. In this case, rural tourism has become the best choice for people to relieve the pressure of life, adjust the tension and experience the natural environment.

\subsection{Higher income level}

According to the international experience, when the per capita GDP exceeds 1000 US dollars, the national tourism demand enters the inflation period, but the expansion is mainly the tourism demand. When the per capita GDP exceeds 2000 US dollars, diversified demands and choices for leisure will be formed. When the per capita GDP exceeds 3000 US dollars, holiday tourism will be generally developed. In today's society, the per capita GDP of many developed countries is more than 3000 US dollars, so leisure tourism has become a hot spot in the rapid development of tourism in the world, and become the first choice of tourists. Therefore, in recent years, China's rapid economic development, which led by tourism economic development significantly. As the characteristic economy that promotes rural development, rural tourism has main position.[2]

\subsection{Promotion of industrial policies, systems and regulations}

Under the condition of market economy, the encouraging policies formulated in the national macro-control can play a great role in promoting the development of rural tourism, such as financial subsidies, tariff relief, preferential loans, credit guarantee and investment incentives. At the legal level, the formulation of the national vacation system and social security system is conducive to the citizens to have enough time and money for leisure consumption. In addition, restrictive clauses can regulate the healthy development of the national leisure industry, restrain the bad leisure consumption habits of the people, and promote the sustainable and healthy development of the leisure industry. Since 1993, in order to encourage national tourism, the state has increased publicity and promotion efforts. Every year, it launches various special tourism activities, many of which are closely related to rural tourism. With the support of macro policy, the rapid development of rural tourism is becoming a natural trend.

\section{TYPES OF RURAL TOURISM}

At present, there are many classification methods of rural tourism, and the representative methods are selected here, as shown in Table 1.

Table 1 Classification of Rural Tourism Villages in China

\begin{tabular}{|l|l|l|}
\hline $\begin{array}{l}\text { Division } \\
\text { criteria }\end{array}$ & type & example or characteristic \\
\hline & Suburban type & $\begin{array}{l}\text { Located in the vicinity of large and medium-sized cities, in order } \\
\text { to meet the huge tourism demand of the city, on the basis of the } \\
\text { original agriculture and modern rural settlement landscape, } \\
\text { modern science and technology, modern beauty and } \\
\text { development. }\end{array}$ \\
\hline $\begin{array}{l}\text { geographical } \\
\text { position }\end{array}$ & Remote type & $\begin{array}{l}\text { Generally, transportation is inconvenient. Most of these types } \\
\text { have rich tourism resources to develop tourism. }\end{array}$ \\
\cline { 2 - 4 } & $\begin{array}{l}\text { Edge type of } \\
\text { scenic spot }\end{array}$ & $\begin{array}{l}\text { At the edge of the famous scenic spots, we can combine the } \\
\text { scenic spots and rely on the existing tourism resources and tourist } \\
\text { resources to develop. }\end{array}$ \\
\hline $\begin{array}{l}\text { Coretourism } \\
\text { resources }\end{array}$ & $\begin{array}{l}\text { Traditional } \\
\text { sightseeing } \\
\text { type }\end{array}$ & $\begin{array}{l}\text { With the agricultural production process unfamiliar to urban } \\
\text { people as the selling point, the characteristic orchard and } \\
\text { vegetable garden will be opened up in the suburb of the city or }\end{array}$ \\
\hline
\end{tabular}




\begin{tabular}{|l|l|l|}
\hline & $\begin{array}{l}\text { near the scenic spot, so that tourists can pick, watch and enjoy the } \\
\text { pastoral fun. }\end{array}$ \\
\hline $\begin{array}{l}\text { Urban science } \\
\text { and technology }\end{array}$ & $\begin{array}{l}\text { With high technology as the main feature, small-scale } \\
\text { agricultural, forestry and animal husbandry production bases will } \\
\text { be established in the suburbs of the city. It can not only provide } \\
\text { fresh products for the city, but also combine agricultural } \\
\text { production and popular science education. }\end{array}$ \\
\hline $\begin{array}{l}\text { Leisure } \\
\text { vacation type }\end{array}$ & $\begin{array}{l}\text { Different agricultural resources, such as forests and orchards, are } \\
\text { used to attract tourists to take vacation and carry out various } \\
\text { leisure and holiday activities such as agricultural experience, } \\
\text { natural ecology appreciation, accommodation and vacation. }\end{array}$ \\
\hline
\end{tabular}

\section{DEVELOPMENT PATH OF RURAL TOURISM}

In the development of rural tourism, we must pay attention to the needs of leisure people and the promotion of their competitiveness; cultural inheritance and cultural innovation go hand in hand, focusing on cultural innovation; and the development of tourism, including rural leisure tourism, requires the restoration of the attributes of tourism resources as public goods, promoting the healthy development of tourism industry.[3]

\subsection{Strengthen planning guidance, pay attention to experience upgrading, rural tourism industry integration development}

Different villages have different characteristics, and the same villages have different problems to be solved in different periods. In view of this situation, we must pay attention to differences when implementing rural revitalization. Philosophically speaking, we should start from reality, pay attention to the differences in the process of rural development, highlight the key points and do a good job in planning, so as to ensure the long-term and stable development of rural areas Qualitative.

a. Strengthen planning guidance

Rural tourism planning not only has the guiding role of regional macro planning, but also has the micro landing significance of key sections of planning and design. Rural tourism must be guided by planning, overall planning, "point to surface, to promote the point", based on the current, planning far-reaching, clear development direction. In the past, rural tourism should change the spatial economic system with scenic spots as the main framework, build different framework models of scenic spots, holiday areas, leisure areas, tourism blocks, tourism towns, tourism demonstration counties and cities, create the spatial system of tourism destinations, and promote the transformation of rural tourism from single scenic spots to tourism centers and tourist destinations.

b. Pay attention to experience upgrading and integrate tourism resources organically

Rural tourism is not only the tourism of agricultural resources, not only just the natural resources such as rural scenery, but also the characteristics of cultural resources such as rural architecture, rural settlements, rural folk customs, rural culture, rural food, rural clothing, agricultural activities and other human resources. It is necessary to develop intangible tourism such as rural economy and society from the special immersion type rural tourism which looks like walking horses and flowers Tourism resources, fully combined with local festival activities, traditional festivals, local customs, residential experience and other elements, dig deep into the connotation, create fashion, and comprehensively upgrade the tourist experience.

c. Integrated development of rural tourism industry, casting excellent demonstration

Rural tourism can activate the traditional agricultural development mode, vigorously develop new business forms such as leisure agriculture, creative agriculture, refined agriculture, popular science agriculture, leisure fishery, etc., and create local "rural life" according to local conditions, so as to integrate the original and native folk culture with business exhibition industry, health care industry, cultural creativity industry and sports industry Innovation to realize the linkage effect of tourism in an all-round way. We will create fine rural tourism demonstration projects such as small towns, villages, characteristic agricultural demonstration parks, science and technology demonstration parks, and theme leisure agricultural parks; in accordance with the principles of high-end, characteristic and high-quality, we will create a quality rural tourism demonstration integrating health care business exhibition, leisure vacation and cultural experience.

\subsection{Pay attention to specialized operation and realize the sustainability of rural tourism development}

The success of rural tourism is not achieved overnight. It needs a continuous process, professional operation and high standard management to enhance the comprehensive competitiveness. First, we should attach importance to operation. We should optimize the decision-making mechanism of villagers' participation in operation and management, improve villagers' enthusiasm, make good use of policy support funds and reduce the investment pressure of enterprises. The second is to standardize the 
management and establish the professional evaluation system of rural tourism. The management of "food, housing, transportation, tourism, shopping and entertainment" in rural areas must be standardized and qualified. The development of elements should be adapted to local conditions and should not be blindly innovated. For example, accommodation in rural tourism must have local characteristics. The third is to do a good job in personnel training and management. Strengthen the professional quality of employees, through the corresponding training with local relevant departments or enterprises, guide the employees to further broaden their professional ability, upgrade their files, and form comprehensive service talents. Introduce relevant preferential policies to attract high-quality talents to start businesses or employment in rural areas. Learning from Lijiang's bar model, we can attract young people from all over the country who have good taste and pursue quality of life to innovate the bar brand. The countryside also has its attractive brand characteristics, mainly young people, middle-aged and elderly people who prefer rural environment, pursue tranquility and enjoy rural scenery and rural life. Therefore, we should boldly provide them with opportunities to create unexpected rural tourism products.

\subsection{To maximize the brand value of rural tourism and enhance its comprehensive competitiveness}

In recent years, rural tourism has developed rapidly, which is full of opportunities and challenges. In the face of the current trend of continuous renewal and diversification of the tourism market, the sustainable development of rural tourism is still facing new marketing problems, such as the low popularity of marketing concepts, few channels, simple methods; more use of low-cost products penetration, low visibility, weak financial strength; lack of regional rural tourism market planning and overall marketing strategies. With the rapid development of tourism, rural tourism marketing is to sell the countryside, life, and comprehensive competitiveness. The most important thing of rural tourism marketing is to make the products have selling points. The fundamental purpose of rural tourism products is to meet the needs of tourists and provide a kind of value for tourists through products. The essence of rural tourism is the perfect combination of natural ecology and traditional culture. At present, China's rural tourism relies too much on the participation of rural tourism and agricultural activities, and lacks the excavation of cultural level. In order to develop the characteristic rural towns, we should try our best to excavate the traditional culture behind them and build our own tourism brand.[4]Through the development of tourism products such as rural tourism, conference and vacation, rural experience, fishermen's leisure, folk customs, festivals and celebrations, we can expand the combination width; through the close combination of eco-tourism and folk culture tourism, we can increase the depth of product portfolio; we can plan festival activities creatively to ignite publicity; we can carry out marketing to improve word-of-mouth; we should innovate seasonal marketing to highlight Features. Of course, as an important component of the rural revitalization strategy, rural tourism has gradually shown a strong development trend in the perspective of the Internet, providing a new opportunity for the revitalization of rural tourism industry.[5]Rural tourism marketing should also be combined with traditional marketing and new media marketing, planning creative activities, creating topics, detonating through Internet marketing channels, and then promoting through traditional marketing.

\subsection{Broaden the field of rural tourism investment and innovate the mode of rural tourism investment}

Under the strategy of rural revitalization, rural tourism has become a new engine of Rural Revitalization. How to do a good job in rural areas and make beautiful villages has become a hot topic at present. In 2016, the No. 1 central document put forward the directive of "perfecting rural financial services", "guiding Internet finance, and developing standardized rural finance in rural areas", giving full attention to the modern rural financial system. Rural tourism investment has grown rapidly. In 2017, the actual investment of rural tourism in China reached 550 billion yuan, with more than 2.5 billion person times received annually. However, rural tourism investment must pay attention to the field and mode of rural tourism investment. We should change the investment content from single product construction to characteristic rural B \& $\mathrm{B}$, resort hotel, historical and cultural village, leisure farm and so on to broaden the field of rural tourism investment; we should strengthen financial support, guide financial capital investment, increase credit support, implement preferential tax policies, expand tourism financing channels, and diversify and innovate rural tourism investment mode.

\section{CONCLUSION}

To implement the strategy of rural revitalization, the general requirements are industrial prosperity, ecological livability, rural civilization, effective governance and rich life. Rural tourism makes use of rural natural resources and human resources, organically combines farming activities with leisure agriculture, traditional agricultural civilization and modern local culture, which can promote the integrated development of rural primary, secondary and tertiary industries, promote the Trinity development of rural production, life and ecology, and effectively promote the revitalization of rural areas. In order to give full play to the important role of rural tourism in rural revitalization, targeted measures should be taken to promote the quality 
and efficiency of rural tourism. Change the driving force mechanism of development. Most of rural tourism in China is developed by rural residents. In this process, some problems inevitably arise, such as the small scale of rural tourism, the lack of characteristics and the weak sustainability. In the new era, we should give full play to the leading role and regulatory function of the government, organically combine rural tourism with beautiful rural construction, make overall arrangements and unified planning for rural infrastructure construction and rural tourism projects, develop rural tourism projects according to local conditions on the basis of fully respecting the wishes of rural residents, and implement regional layout and differentiation of rural tourist attractions Design, strive to create a rural tourism brand with local characteristics.

\section{REFERENCES}

[1] Chen Jia, Yang Xinjun, Wen Xin, Deng Mengqi, theoretical framework and empirical evidence of rural adaptive evolution in the context of Tourism Development, Journal of Natural Resources, 07(2020), Pp. 16.

[2] Li Zhou, development strategy of Rural Leisure tourism in the context of rural revitalization strategy

On the public welfare of natural landscape resources, quest, 04(2020), Pp. 14-21.

[3] Li Zhou, development strategy of Rural Leisure Tourism under the background of Rural Revitalization Strategy — On the public welfare of natural landscape resources, seeking, 042020, Pp. 14-21.

[4] Zhou Zheng, research on the development path of characteristic small town under the perspective of rural revitalization, China Business Review, 14(2020), pp. 161-163.

[5] Guo Yanrong, the renewal of rural tourism model based on Internet, Jushe, 34(2019), Pp. 8. 